\title{
A NEW COMBINATION IN MIRANDEA (ACANTHACEAE)
}

\author{
Thomas F. Daniel \\ Department of Botany \\ California Academy of Sciences \\ Golden Gate Park \\ San Francisco, California 94118, U.S.A.
}

\begin{abstract}
Based on macromorphological, palynological, and preliminary molecular data, Pachystachys nutans Nees is transferred to Mirandea. The species is described and lectotypified. A key to the six species of this wholly Mexican genus is provided.
\end{abstract}

Key words: Acanthaceae, Mexico, Mirandea, Pachystachys.

\section{RESUMEN}

De acuerdo con datos macromorfológicos, palinológicos, y moleculares preliminares, se transfiere Pachystachys nutans Nees a Mirandea. Se describe la especie y se le designa un lectotipo. Se presenta una clave para las seis especies de este género endémico de México.

Palabras clave: Acanthaceae, México, Mirandea, Pachystachys.

The genus Mirandea Rzed. consists of perennial herbs and shrubs occurring in the deserts and thornscrub of northeastern Mexico and in the moist to wet forests of southern Mexico (Acosta, 1985; Daniel, 1986; Daniel, in press). Preparation of a treatment of Acanthaceae for the Flora del Bajío y de Regiones Adyacentes (Calderón de Rzedowski and Rzedowski, 1991) necessitated the reevaluation of the taxonomy of an enigmatic species of Mexican Acanthaceae, Pachystachys nutans Nees. Based on morphological and preliminary molecular sequence data, this species appears to be more closely affiliated with Mirandea.

Mirandea nutans (Nees) T. F. Daniel, comb. nov. Pachystachys nutans Nees in A. de Candolle, Prodr. 11: 320. 1847. Jacobinia nutans (Nees) Hemsl., Biol. Cent.-Amer., Bot. 2: 521. 1882. TYPE: MEXICO. Hidalgo: barranca del Río de Tolimea (Tolimán) prope las Ajuntas (Adjuntas) ad Caracol [Urban (1897) noted that in January 1840, Ehrenberg and Ortiz traveled via the Caracol to Ajuntas and collected extensively on the slopes of the Río Moctezuma], C. Ehrenberg 1060 (holotype: B, destroyed; lectotype, designated here: PR!; probable isotypes: BM, GH, GZU, P!, POM!, VT).

Shrubs to $1.5 \mathrm{~m}$ tall. Young stems subquadrate, evenly and more or less densely pubescent with antrorse to flexuose to retrorse eglandular trichomes $0.1-0.3(-0.5) \mathrm{mm}$ long. 
Leaves petiolate, petioles to $12 \mathrm{~mm}$ long, blades ovate, $12-45 \mathrm{~mm}$ long, 5.5-19 mm wide, 1.8-2.5 times longer than wide, acuminate to acute at apex, rounded to acute to subattenuate at base, surfaces and margin pubescent with antrorse eglandular trichomes to $0.5 \mathrm{~mm}$ long, abaxial surface also pubescent along midvein (at least proximally) with flexuose eglandular trichomes to $2 \mathrm{~mm}$ long, margin entire. Inflorescence of terminal conspicuously bracteate 4-sided pedunculate dichasiate spikes to $75 \mathrm{~mm}$ long (including peduncle and excluding flowers), peduncles to $5 \mathrm{~mm}$ long, pubescent like young stems, rachis evenly pubescent with glandular trichomes to $0.05 \mathrm{~mm}$ long and mostly erect eglandular to subglandular trichomes 0.05-0.2 mm long; dichasia opposite, 1 per axil, 1-3-flowered, sessile. Bracts pale when dry (i.e., colored differently than leaves), imbricate, opposite, broadly ovate to elliptic, 10-17 mm long, 6-14 $\mathrm{mm}$ wide, acute to acuminate at apex, abaxial surface pubescent with mostly erect glandular and eglandular trichomes 0.05-0.2 $\mathrm{mm}$ long and with a few longer antrorse to flexuose eglandular trichomes mostly on and near midvein, margin more or less densely ciliate with flexuose eglandular trichomes to $2 \mathrm{~mm}$ long. Bracteoles subulate, $0.5-3 \mathrm{~mm}$ long, 0.2-0.6 mm wide, pubescent like bracts; secondary bracteoles (if present) similar to bracteoles in shape but smaller in size. Flowers sessile to subsessile (i.e., borne on pedicels to $1 \mathrm{~mm}$ long). Calyx 5-lobed, 3.2-5 mm long, lobes subulate to lance-subulate, $2.8-3.5 \mathrm{~mm}$ long, 0.5-0.7 $\mathrm{mm}$ wide, abaxially pubescent with erect to antrorse eglandular and subglandular trichomes to $0.2 \mathrm{~mm}$ long. Corolla blue-purple, subcylindric to obovoid in bud, $17-21 \mathrm{~mm}$ long, externally pubescent with erect to flexuose eglandular trichomes $0.05-0.8 \mathrm{~mm}$ long, internal surface of lips pubescent with mostly erect glandular and eglandular trichomes to $0.05 \mathrm{~mm}$ long, tube 5-6 mm long, 0.33-0.50 times as long as lips, \pm abruptly expanded distally, upper lip 12-16 mm long, 2-lobed, lobes $0.2 \mathrm{~mm}$ long, lower lip 11-14 mm long, lobes 3$5 \mathrm{~mm}$ long, 2-3 mm wide. Stamens $12-15 \mathrm{~mm}$ long, filaments pubescent with eglandular trichomes throughout, thecae 2.6-3.8 $\mathrm{mm}$ long, equal to subequal, parallel to subsagittate, equally inserted, glabrous, lacking basal appendages; pollen 3-colporate, 6-pseudocolpate. Style 7-16 mm long, pubescent with eglandular trichomes, stigma 2-lobed, lobes 0.1-0.2 mm long or sometimes indistinct. Capsule $13 \mathrm{~mm}$ long, pubescent with erect to flexuose eglandular trichomes $0.05-0.2 \mathrm{~mm}$ long, stipe $5 \mathrm{~mm}$ long, head subellipsoid, $8 \mathrm{~mm}$ long. Seeds not seen.

Phenology. Flowering: January, May, October; fruiting: May.

Distribution and habitat. Northeastern Mexico (Hidalgo, Querétaro); plants occur in thornscrub at elevations of about 1100 meters.

Typification. A duplicate of the destroyed holotype from B, bearing both the number (1060) and locality cited in the protologue, is present at PR. This specimen is designated as the lectotype. Specimens collected by Ehrenberg in Mexico, but lacking both the collector's number and locality information have been located in several herbaria. They are presumed to be isotypes.

Additional specimens examined. MÉXICO. Hidalgo: Zimapán, T. Coulter $1122(\mathrm{~K})$; mpio. Zimapán, $400 \mathrm{~m} \mathrm{E}$ de Las Adjuntas, $1100 \mathrm{~m}$, matorral submontano, 24 October 1991, V. Huerta B. 1398 (MEXU). Querétaro: mpio. Cadereyta, 2 km al W de Las Moras, 
camino a San Joaquin, 1100 m, matorral submontano, 12 May 1997, J. Rzedowski 53366 (IEB).

Discussion. Wasshausen (1986) excluded Pachystachys nutans from Pachystachys Nees because the available material of the species was insufficient to ascertain its generic disposition. Furthermore, all of the species treated in the genus by Wasshausen (1986) are South American (with one species extending into the Caribbean) in their distribution. Additional collections referable to this species have been located, some of them collected recently (e.g., Rzedowski 53366 and Huerta B. 1398). Pollen of $P$. nutans (Fig. 1) more closely resembles that of Pachystachys (Wasshausen 1986) and other genera in the "Tetramerium Lineage" (McDade et al., 2000) than Justicia (including Jacobinia, into which genus the species was transferred by Hemsley; see descriptions and images in Daniel 1998). It appears that a stylar furrow (or rugula) is not present on the upper lip of the corolla (plants referable to Justicia have rugulate corollas). Preliminary molecular sequence data from the rps16 chloroplast gene (McDade pers. comm.) places this species in the "Tetramerium Lineage", in the vicinity of Yeatesia and Mirandea. Genera in this lineage have a long history of taxonomic recognition, but apomorphic characters have been identified for very few of them (Daniel and Chuang, 1993; McDade et al., 2000).

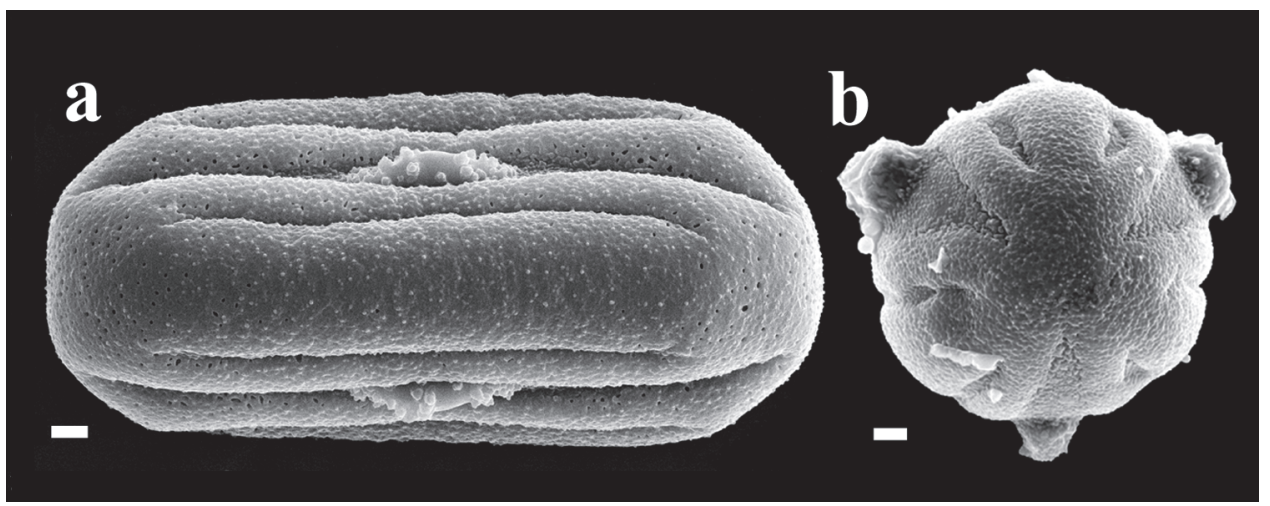

Fig. 1. Pollen of Mirandea nutans. a. equatorial, intercolpal view (Huerta B. 1398). b. polar view (Ehrenberg s. n.). Scales $=3 \mu \mathrm{m}$.

Pachystachys nutans shares most of the characters associated with Mirandea and "keys" to this genus in generic keys involving the "Tetramerium Lineage" (e.g., Daniel 1982, 1986b). Like other species of Mirandea from northern Mexico, $P$. nutans has purplish corollas; like $M$. hyssopus, it has glands on the internal surface of the lips of the corolla; and like other species of the genus, the style is recurved near the apex. Thus, based on the observable morphological attributes and preliminary molecular data, this species is herewith transferred to Mirandea. It differs from the other species in the genus by the 
relatively short corolla tube (0.33-0.50 times as long as lips vs. equaling or longer than lips), the longer stamens (12-15 vs. $4.5-9 \mathrm{~mm}$ long), and the usually longer thecae (2.6-3.8 vs. 1.3-2.8 mm long). The species of the wholly Mexican genus Mirandea can be distinguished using the following key:

1 Bracts imbricate, broadly ovate to elliptic to subcircular, 6-14 $\mathrm{mm}$ wide, obscuring calyx and bracteoles; plants of Querétaro and Hidalgo.

2 Leaves 3-7 times longer than wide; bracteoles lanceolate to lance-ovate to elliptic, 4.5$10 \mathrm{~mm}$ long, 1.4-3.5 mm wide; corolla tube longer than limb, upper lip of corolla 5.3$9 \mathrm{~mm}$ long; stamens $5.5-7 \mathrm{~mm}$ long, filaments pubescent with glandular trichomes M. hyssopus (Nees) T. F. Daniel

2 Leaves 1.8-2.5 times longer than wide; bracteoles subulate, 0.5-3 mm long, 0.2-0.6 mm wide; corolla tube shorter than limb, upper lip of corolla $12-16 \mathrm{~mm}$ long; stamens $12-$ $15 \mathrm{~mm}$ long, filaments pubescent with eglandular trichomes

M. nutans (Nees) T. F. Daniel

1 Bracts not or scarcely imbricate, triangular to subulate to linear to narrowly elliptic to lanceolate to narrowly ovate to oblanceolate, 0.5-3 mm wide, not obscuring calyx and bracteoles; plants not known from Querétaro and Hidalgo.

3 Corollas yellow; leaves petiolate, petioles 8-105 mm long, blades 50-200 mm long, 18$105 \mathrm{~mm}$ wide, rounded to cordate at base; dichasia (1-) 3-many-flowered, borne on peduncles to $13 \mathrm{~mm}$ long; bracts $0.5-0.8 \mathrm{~mm}$ wide; plants of rain forests in southern Mexico (Chiapas, Oaxaca, Tabasco, Veracruz)

M. sylvatica Acosta

3 Corollas bluish or purplish; leaves sessile to short-petiolate, petioles 1-3 mm long, blades 3-40 $\mathrm{mm}$ long, 1-7 mm wide, obtuse to acute to acute-attenuate at base; dichasia 1flowered, sessile or borne on peduncles to $4.5 \mathrm{~mm}$ long; bracts $0.8-3 \mathrm{~mm}$ wide; plants of deserts and regions of thornscrub in central and northern Mexico.

4 Leaves linear to linear-oblanceolate, 7-20 times longer than wide; bracts 8-16 (-20) mm long; calyx 5-7 mm long; style glabrous; capsules glabrous; plants of Tamaulipas M. andradenia T. F. Daniel

4 Leaves lance-linear to lanceolate, ovate, elliptic, oblanceolate or obovate, 2-7 times longer than wide; bracts 1-6 mm long; calyx 3.5-5 mm long; style pubescent; capsules pubescent.

5 Leaf margin flat, ciliate; dichasia pedunculate (peduncles 2-4.5 mm long), 1 per node, mostly secund; bracts narrowly ovate to narrowly elliptic, 2-4 mm long, eglandular; plants of Nuevo León M. huastecensis T. F. Daniel

5 Leaf margin revolute, eciliate; dichasia sessile, opposite at nodes, not secund; bracts lanceolate to subulate, 4.5-6 mm long, sometimes glandular; plants of San Luis Potosí and Tamaulipas M. grisea Rzed.

\section{ACKNOWLEDGMENTS}

I am grateful for loans of Mexican Acanthaceae from the following herbaria: CAS, IEB, K, MEXU, P, and POM. Funds to study Acanthaceae at IEB were provided by the California Academy of Sciences. I thank J. Rzedowski, G. Calderón de Rzedowski, S. 
Zamudio, and V. Steinmann for assisting with my visit there. Scott Serata supervised operation of the scanning electron microscope.

\section{LITERATURE CITED}

Acosta C., S. 1985. Algunas especies interesantes de la familia Acanthaceae en México. Phytologia 57: 249-260.

Rzedowski, J., G. C. de Rzedowski and S. Zamudio. 1991. Presentación. Flora del Bajío y de Regiones Adyacentes. Fascículo Complementario 1: 1-4.

Daniel, T. F. 1982. The genus Mirandea (Acanthaceae). Contr. Univ. Michigan Herb. 15: 171-175.

Daniel, T. F. 1986a. New and reconsidered Mexican Acanthaceae. II. Southw. Natural. 31: 169-175.

Daniel, T. F. 1986b. Systematics of Tetramerium (Acanthaceae). Syst. Bot. Monogr. 12: 1-134.

Daniel, T. F. 1998. Pollen morphology of Mexican Acanthaceae: diversity and systematic significance. Proc. Calif. Acad. Sci. 50: 217-256.

Daniel, T. F. and T. I. Chuang. 1993. Chromosome numbers of New World Acanthaceae. Syst. Bot. 18: $283-289$

McDade, L. A., T. F. Daniel, S. E. Masta, and K. M. Riley. 2000. Phylogenetic relationships within the tribe Justicieae (Acanthaceae): evidence from molecular sequences, morphology, and cytology. Ann. Missouri Bot. Gard. 87: 435-458.

Urban, I. 1897. Biographische Skizzen. V. Carl August Ehrenberg (1801-1849). Bot. Jahrb. Syst. 24 (Beiblatt 58): 1-13.

Wasshausen, D. C. 1986. The systematics of the genus Pachystachys (Acanthaceae). Proc. Biol. Soc. Wash. 99: 160-185. 